\title{
DETERMINATION OF REGIONAL PRESENCE OF MALE BODY TYPES AS A PREREQUISITE FOR IMPROVING GARMENT MANUFACTURE
}

\author{
Ksenija Doležal, Renata Hrženjak, Darko Ujević, \\ University of Zagreb, Faculty of Textile Technology, Department of Clothing Technology, Zagreb, Croatia \\ e-mail: ksenija.dolezal@ttf.hr
}

\begin{abstract}
:
Garment manufacture and garment fit to physique is a never-ending research subject. The human body is subject to changes that are reflected in its shape and body measurements, and appear in all periods of life. Monitoring the changes and gaining insight into the actual amounts of physical dimensions of an individual population unfold numerous opportunities to affect clothing design and manufacturing. In accordance with the issues mentioned above, a research was carried out to determine male body types of the Croatian male population. Male body types for a specific clothing size determine waist and hip girth, which completes the information on main body measurement amounts. Furthermore, the types of bodies are prescribed by the European Standard 14302-3 and, accordingly, in the observed sample, the presence of a particular type is determined with respect to regional affiliation and age. This study was conducted on a sample of 4090 test subjects divided into five regions, ages 20 to 85 years, divided into seven age groups. By statistical analysis of the results, that is, by the methods of descriptive statistics, the values of physical dimensions necessary for this research were determined.
\end{abstract}

\section{Keywords:}

Body types, anthropometric measurements, standards, garment fit

\section{Introduction}

The shape of the human body constantly changes throughout life. The changes that occur are reflected in the values of individual body measurements, changing the values of the main girths (chest, waist and hips). If the knowledge thereof is applied to making clothes in the field of design and modeling, this will result in raising the quality of end products. One of the most important factors that should be satisfied when designing garments is garment fit or adaptation to body shape of as many consumers as possible. Good fit of manufactured clothing ensures successful market placement, and consideration of the issue of clothing compliance takes into account research based on anthropometric findings. So, the results of anthropometric measurements of the human body, conducted on a representative sample form the basis for determining garment sizes of a certain population $[1,2]$.

Furthermore, the European clothes' size labelling standards belong to series EN 13402 (13402-1, 13402-2 and 13402-3) and are binding for all the EU countries as well as those that export their products to the European market. However, when creating a system of clothing sizes, EN 13402 may be augmented with the data of actual deviations of body proportions of a substantial part of the population, individual region or country, for which they are designed, from the values regulated by the standard [3,4]. If differences in body proportions are found to exist, a national standard of clothing sizes fully adapted to the measured population is established [5]. The Republic of Croatia solved its own problems associated with inadequate clothing sizes in this way. Specifically, the former standard JUS (Yugoslav Standard) was in use, and after the creation of the
Croatian state, JUS was renamed to HRN (Croatian Standards) and continued to be used in the original form [1]. However, HRN soon became unacceptable because of the increasing deviation of prescribed physical measurements from the actual ones, and it became necessary to take new anthropometric population measurements. In 2004, the compound technological project "Croatian Anthropometric System" (STIRP HAS) was started within which 30,866 test subjects of all ages were measured in the Republic of Croatia. Numerous data collected as part of STIRP HAS created a database to determine clothing sizes, which was published in the Croatian Technical Report (HRI) in 2012. This report prescribes clothing sizes in a way that is specified by a letter and a numeric mark, where the letter designation determines the body type $[1,6]$.

The study will investigate:

1. The mean values of anthropometric measures (chest girths and waist girths) of the male population.

2. Regional and age differences of the established values of chest and waist girths of the male population.

The aim of this paper is to determine the regional presence of male body types in the measured sample.

\subsection{Garment size systems}

In the garment size system, individual body dimensions define a garment size and create a scale specified by a standard. The standard defines body shape based on two dimensions of girth - basic and dependent variables. Furthermore, the 
classification of data of body measurements results in their grouping in garment sizes of the population. On the basis of this information, garment size tables with information on the differences in body shape and proportions create a clothing size system $[6,7]$. When creating a clothing size system, it is necessary to find out how clothing sizes are labeled, which is also regulated in the standard. According to HRN (Croatian Standards), the size designation of men's outerwear comprises labels that show figure development, measurements of chest girth and stature. According to ISO 3635, there are four basic starting points: 1 . Use of body measurements, 2. Use of metric system, 3. Use of one to three characteristic measurements and 4 . Introduction of pictograms.

Complete anthropometric surveys of measurements and how they are taken are provided in ISO 8559 which prescribes taking 26 horizontal and 27 vertical measurements and two additional measurements [6]. Size designation of clothes according to EN 13402 (13402-1, 13402-2, 13402-3 and 13402-4) is completely based on ISO standards, Figure $1[5,8,9]$.

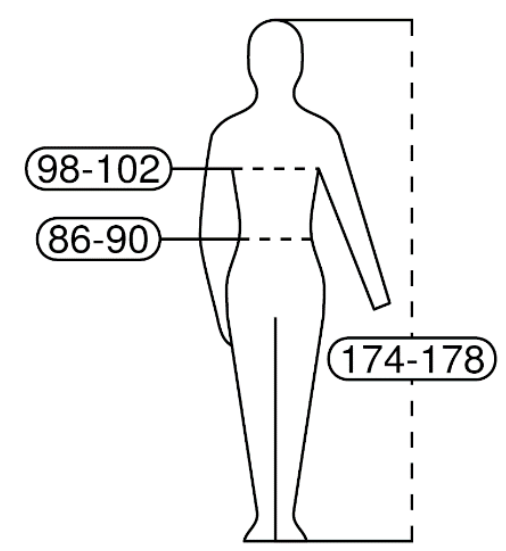

Figure 1. Example of a pictogram to designate men's garment size according to EN 13402-1[6].

A clothing size system is a basic starting point in industrial garment manufacture, since it provides some insight into real needs of consumers. Therefore, manufacturers who sell products in a specific country should have access to data describing body sizes and shapes of the target population $[7,9]$.

\subsection{Croatian Technical Report - National Addendum of the Republic of Croatia to European Standards (EN)}

The data on actual body dimensions of the Croatian population collected with anthropometric measurements showed certain discrepancies with the general EN. For this reason, a national supplement - Croatian Technical Report - was created [9].

The goal of the report was:

- To provide a thorough understanding of the classification of clothing according to size in order to improve the suitability and fit for the population of Croatia,

- To optimize the number of garment sizes especially designed for the Croatian population,
- To facilitate the technical cooperation between manufacturers, sellers and customers as end consumers [1,9].

Determining the appropriate clothing sizes meets the requirements of garment fit for a large number of customers, resulting in the introduction of a system of clothing sizes and higher garment production rates.

\subsection{Proposal of the Croatian garment system for men's clothing}

Chest girth provides a basis for the designation of men's clothing sizes. Anthropometric measurements within STIRP HAS showed that a statistically significant part of the male population has a chest girth ranging from 84 to $132 \mathrm{~cm}$. The range among clothing sizes amounts to $4 \mathrm{~cm}$ for chest girth from $84 \mathrm{~cm}$ to $120 \mathrm{~cm}$ and $6 \mathrm{~cm}$ for chest girth from $120 \mathrm{~cm}$ to $132 \mathrm{~cm}$. The above data reveals that the size system for men's clothing foresees 12 different chest girths [9]. By measuring, it was found that a statistically significant part of the Croatian male population has a body height from $160 \mathrm{~cm}$ to $192 \mathrm{~cm}$. Since the standard prescribes a certain height range among individual statures of $8 \mathrm{~cm}$ for general use (an increment of $4 \mathrm{~cm}$ for trousers), five different statures were determined. European Standard (EN) specifies 8 types of male body based on the difference between chest and waist girth. The above mentioned anthropometric measurements confirm that part of the Croatian male population has waist girth in comparison to chest girth larger than the largest defined in EN 14302-3. This is the reason why a $9^{\text {th }}$ type (type I) of male body has been proposed while developing the Croatian system of clothing sizes $[5,9]$.

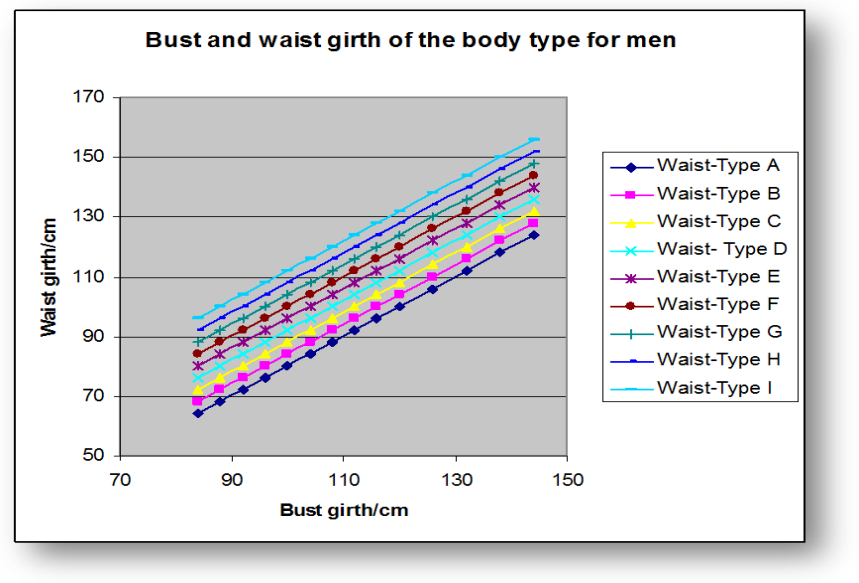

Figure 2. Bust waist girth of the body type for man

Comparison of the JUS (1963) men's clothing sizes and the results of the Croatian Anthropometric System HRI (2012): JUS F.GO.003 (Clothing Size for Men's Garments) establishes five groups of body height and three groups of body shapes. The mean value of the chest girth was $104 \mathrm{~cm}$, the waist girth was $96 \mathrm{~cm}$, and the body height was $172 \mathrm{~cm}$.

HRI 1148: 2012 (Men's clothing systems) establishes five groups of body height and nine types of body (Figure 2). The mean value of the chest girth is $102 \mathrm{~cm}$, the waist girth is 95 $\mathrm{cm}$, and the body height is $176 \mathrm{~cm}$. 
Table 1. Men's body type [6]

\begin{tabular}{|l|c|c|}
\hline Body type & Difference & Wg - Ch $=$ \\
\hline Type A - very slim & -20 & From -22 to -18 \\
\hline Type B - slim & -16 & From -18 to -14 \\
\hline Type C - normal & -12 & From -14 to -10 \\
\hline Type D - sturdy & -8 & From -10 to -6 \\
\hline Type E - sturdier & -4 & From -6 to -2 \\
\hline Type F - corpulent & -0 & From -2 to +2 \\
\hline Type G - paunchy & +4 & From +2 to +6 \\
\hline Type H - markedly paunchy & +8 & From +6 to +10 \\
\hline Type I - very paunchy & +12 & From + 10 to +14 \\
\hline
\end{tabular}

Table 2. Statures for designating sizes for men's clothing in $\mathrm{cm}$ [6]

\begin{tabular}{|l|c|c|c|c|c|}
\hline \multicolumn{7}{|c|}{ Men's body height in cm with a range of 8 cm } \\
\hline Height & 160 & 168 & 176 & 184 & 192 \\
\hline Range & $156-164$ & $164-172$ & $172-180$ & $180-188$ & $188-196$ \\
\hline
\end{tabular}

Table 3. Measurements of chest girth in cm per types of male bodies $[6,9]$

\begin{tabular}{|c|c|c|c|c|c|c|c|c|c|c|c|c|c|c|}
\hline Chest girth & 84 & 88 & 92 & 96 & 100 & 104 & 108 & 112 & 116 & 120 & 126 & 132 & 138 & 144 \\
\hline \multicolumn{15}{|l|}{ Waist type A } \\
\hline Waist girth & 64 & 68 & 72 & 76 & 80 & 84 & 88 & 92 & 96 & 100 & 106 & 112 & 118 & 124 \\
\hline \multicolumn{15}{|l|}{ Waist type B } \\
\hline Waist girth & 68 & 72 & 76 & 80 & 84 & 88 & 92 & 96 & 100 & 104 & 110 & 116 & 122 & 128 \\
\hline \multicolumn{15}{|l|}{ Waist type C } \\
\hline Waist girth & 72 & 76 & 80 & 84 & 88 & 92 & 96 & 100 & 104 & 108 & 114 & 120 & 126 & 132 \\
\hline \multicolumn{15}{|l|}{ Waist type D } \\
\hline Waist girth & 76 & 80 & 84 & 88 & 92 & 96 & 100 & 104 & 108 & 112 & 118 & 124 & 130 & 136 \\
\hline \multicolumn{15}{|l|}{ Waist type E } \\
\hline Waist girth & 80 & 84 & 88 & 92 & 96 & 100 & 104 & 108 & 112 & 116 & 122 & 128 & 134 & 140 \\
\hline \multicolumn{15}{|l|}{ Waist type F } \\
\hline Waist girth & 84 & 88 & 92 & 96 & 100 & 104 & 108 & 112 & 116 & 120 & 128 & 132 & 138 & 144 \\
\hline \multicolumn{15}{|l|}{ Waist type $\mathbf{G}$} \\
\hline Waist girth & 88 & 92 & 96 & 100 & 104 & 108 & 112 & 116 & 120 & 124 & 130 & 136 & 142 & 148 \\
\hline \multicolumn{15}{|l|}{ Waist type $\mathbf{H}$} \\
\hline Waist girth & 92 & 96 & 100 & 104 & 108 & 112 & 116 & 120 & 124 & 128 & 134 & 140 & 146 & 152 \\
\hline \multicolumn{15}{|l|}{ Waist type I } \\
\hline Waist girth & 96 & 100 & 104 & 108 & 112 & 116 & 120 & 124 & 128 & 132 & 138 & 144 & 150 & 156 \\
\hline
\end{tabular}




\section{Experimental}

\subsection{Material and Methods}

This study covers a sample of 4090 men, residents of Croatia, aged 20-85 years. Depending on the age, the test subjects were divided into ten-year age groups (except for the last group) and in total there were seven. Moreover, along with the age division, there is also a regional division since Croatia, for the purposes of this study, was divided into five sections (regions). The regions are: Primorje-Gorski Kotar (Croatian Littoral and Gorski Kotar), Slavonia, Central Croatia, Dalmatia and the City of Zagreb (Figure 3).

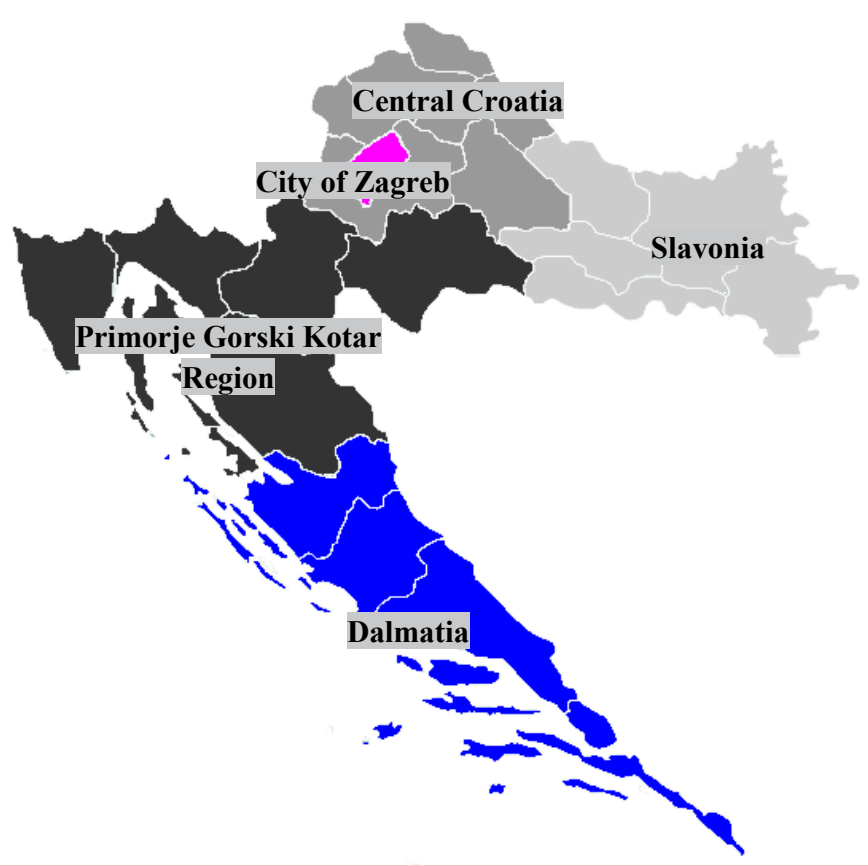

Figure 3. Regions of the Republic of Croatia

Within these regions, the sample included $0.27 \%$ of men of the Primorje-Gorski Kotar Region, $0.26 \%$ of men from Slavonia, $0.19 \%$ of men from Central Croatia, $0.28 \%$ of men from Dalmatia and $0.24 \%$ of men from the City of Zagreb. The quantity of the measured population within each region and Croatia as a whole confirms the significance of the results. The measurements required for this study were carried out within the framework of the compound technological project "Croatian Anthropometric System" (STIRP CAS) whereby the standardized method was used $[10,11]$. The measurement process was carried out using a measuring tape, which is also part of the set of anthropometric instruments, in accordance with ISO 3635, ISO 8559 and EN 13402. After completion, the measurement data was recorded in pre-prepared tables $[12,13]$. On a sample of test subjects, two body dimensions (chest girth and waist girth) were measured.

Descriptive statistics were used to study the complex system of body measurements on the specified sample of Croatian men $[14,15]$. Descriptive statistics involve estimating the parameters of central tendency (mean and median) and dispersion (standard deviation, coefficient of variation and range of data). The distribution of body measurements included in this study were tested for normality with the Kolmogorov-Smirnov test, and they were verified with corresponding graphical representations (histograms) [15,16].

The aforementioned methods used for descriptive grouping are univariate data analysis methods by which body measurements are analyzed one by one or at the most pair by pair. Body measurements, however, constitute a unique and interconnected system to describe the structure (morphology) of the body so that univariate methods generate more or less dependent partial relationships. The description and data processing was performed using software packages Statistica and SPSS and using technical literature $[14,16]$.

\section{Results}

Since the types of male bodies are specified with the waist-tochest ratio, the aim of this study is to establish their regional presence; for this reason, it is necessary to determine the average value of the specified dimensions (Figure 4). The distributions of chest girths of men by age groups (tested with the Kolmogorov-Smirnov test) are shown in Figure 5, and Table 4 gives the basic parameters of the distributions of chest girths for men according to the Croatian regions and age groups

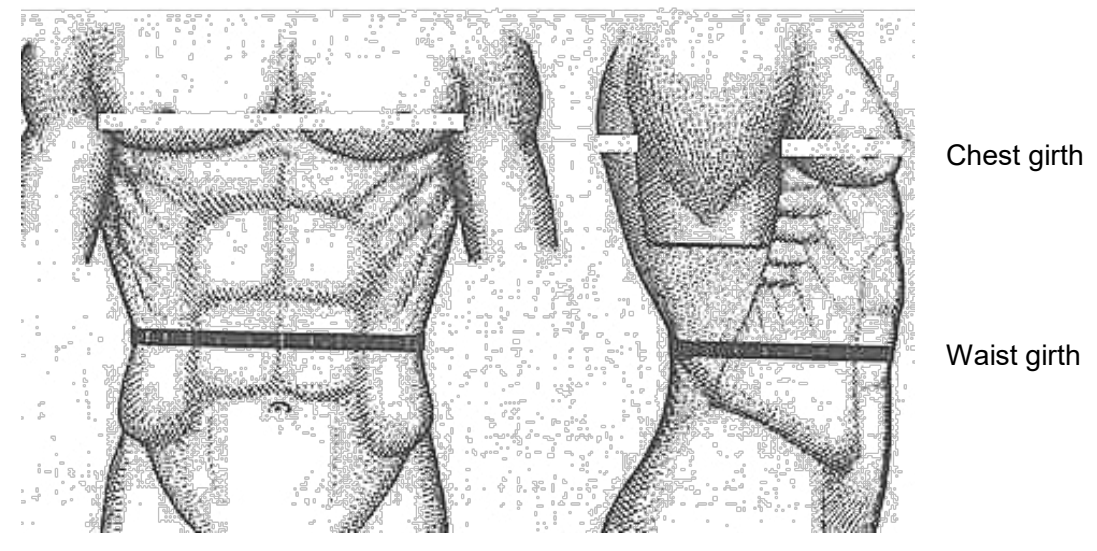

Figure 4. Chest girth and waist girth on a man's body 


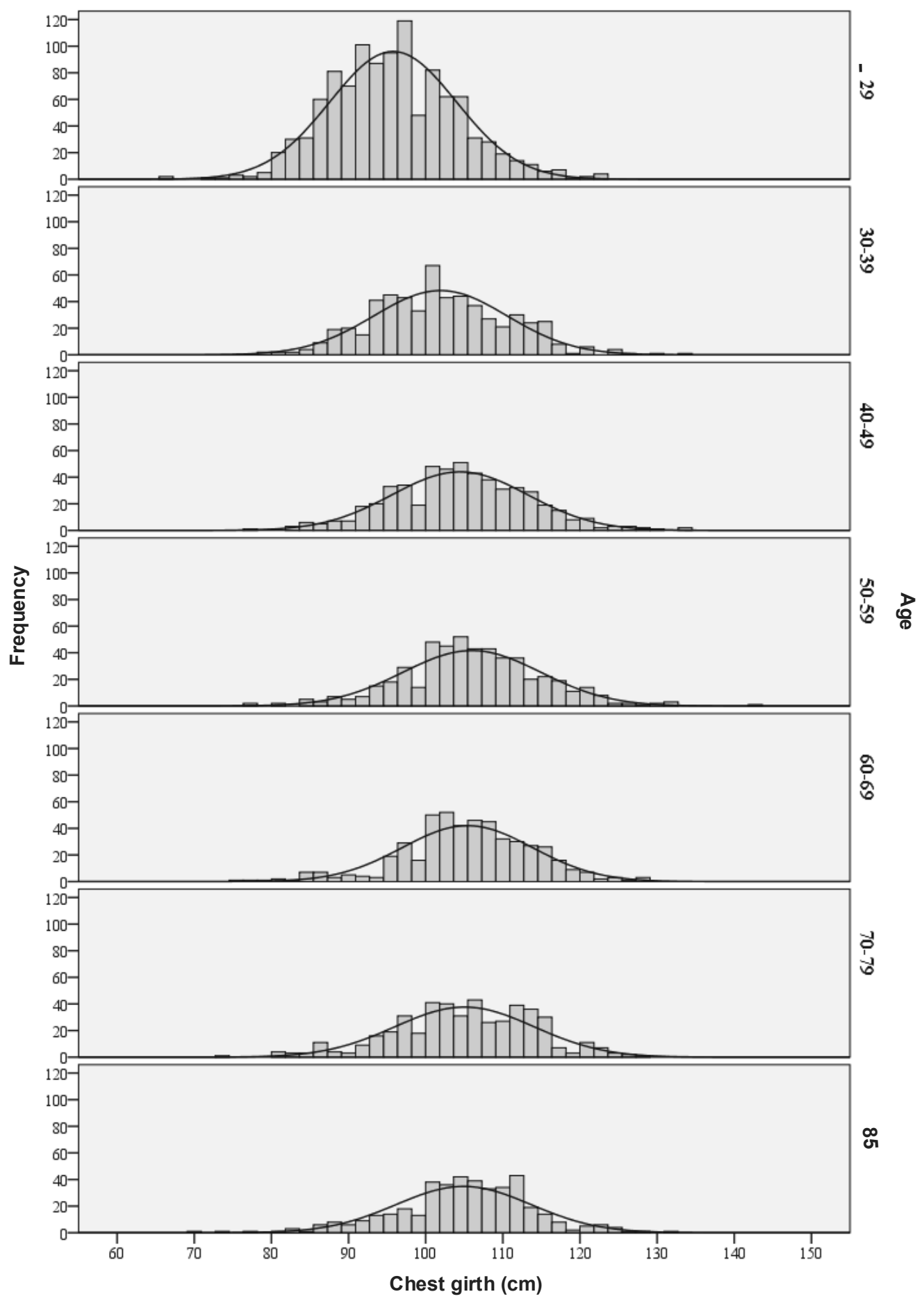

Figure 5. Distributions of chest girths of men by age groups $(N=4,090)$

within the regions.[17-19]

Figure 6 shows the distributions of waist girth of men by age group (tested with the Kolmogorov-Smirnov test), and Table 5 gives the basic parameters of the distribution of waist girth of men according to regions of Croatia and age groups within the regions.

\section{Discussion}

The mean values of chest girths of men changed significantly depending on age in all Croatian regions. Figure 6 shows the shift of chest girth to higher values from the youngest age group aged 20 to 29 years to the group aged 50 to 59 years. Furthermore, there is an equal and notable stagnation and decline of observed values in test subjects in all the regions of Croatia aged from 60-69 years all the way to the oldest age group. The greatest difference in the observed girth occurred in the oldest age group within two regions (Central Croatia and the City of Zagreb). In fact, in the oldest age group of subjects in Central Croatia chest girth reduced compared to the previous year, while in Zagreb it increased, and the difference between the observed values of the two regions is $4 \mathrm{~cm}$. Data analysis 
AUTEX Research Journal, Vol. 18, No 3, September 2018, DOI: 10.1515/aut-2017-0023 @ AUTEX

Table 4. Basic parameters of distributions of chest girths of men $(\mathrm{cm})$ by the regions and age groups

\begin{tabular}{|c|c|c|c|c|c|c|}
\hline \multirow{2}{*}{ Region } & \multirow{2}{*}{ Age } & \multirow{2}{*}{$\mathbf{N}^{a}$} & \multirow{2}{*}{$\bar{x}$ b } & \multirow{2}{*}{$\mathbf{s}^{c}$} & \multicolumn{2}{|c|}{ Range } \\
\hline & & & & & Min. & Max. \\
\hline \multirow{8}{*}{$\begin{array}{l}\text { Primorje Gorski Kotar } \\
\text { Region }\end{array}$} & -29 & 250 & 95.7 & 8.5 & 75.0 & 120.5 \\
\hline & $30-39$ & 128 & 103.4 & 9.5 & 80.0 & 134.0 \\
\hline & $40-49$ & 125 & 105.9 & 8.7 & 82.0 & 128.5 \\
\hline & $50-59$ & 108 & 105.5 & 8.3 & 88.0 & 132.0 \\
\hline & $60-69$ & 117 & 104.9 & 8.8 & 78.0 & 122.0 \\
\hline & $70-79$ & 111 & 105.7 & 8.9 & 85.0 & 128.0 \\
\hline & $80-$ & 98 & 105.3 & 7.0 & 82.0 & 119.0 \\
\hline & Total & 937 & 102.6 & 9.5 & 75.0 & 134.0 \\
\hline \multirow{8}{*}{ Slavonia } & -29 & 195 & 94.2 & 7.9 & 80.0 & 122.0 \\
\hline & $30-39$ & 114 & 101.2 & 7.1 & 87.0 & 124.0 \\
\hline & $40-49$ & 110 & 102.5 & 7.8 & 78.0 & 119.0 \\
\hline & $50-59$ & 121 & 105.3 & 8.4 & 85.0 & 142.0 \\
\hline & $60-69$ & 109 & 106.2 & 8.3 & 81.0 & 124.0 \\
\hline & $70-79$ & 102 & 105.4 & 9.0 & 83.0 & 123.0 \\
\hline & $80-$ & 79 & 105.9 & 10.2 & 73.0 & 131.0 \\
\hline & Total & 830 & 101.9 & 9.5 & 73.0 & 142.0 \\
\hline \multirow{8}{*}{ Central Croatia } & -29 & 186 & 95.9 & 8.1 & 78.0 & 115.0 \\
\hline & $30-39$ & 108 & 101.5 & 8.2 & 80.0 & 124.0 \\
\hline & $40-49$ & 91 & 105.5 & 8.8 & 84.0 & 133.5 \\
\hline & $50-59$ & 96 & 107.7 & 10.7 & 81.0 & 131.0 \\
\hline & $60-69$ & 81 & 107.4 & 9.3 & 84.0 & 129.0 \\
\hline & $70-79$ & 90 & 103.9 & 10.5 & 73.0 & 124.0 \\
\hline & $80-$ & 81 & 102.5 & 10.0 & 70.0 & 125.0 \\
\hline & Total & 733 & 102.4 & 10.2 & 70.0 & 133.5 \\
\hline \multirow{8}{*}{ Dalmatia } & -29 & 233 & 96.6 & 8.5 & 66.0 & 120.0 \\
\hline & $30-39$ & 149 & 100.3 & 8.5 & 79.0 & 129.5 \\
\hline & $40-49$ & 125 & 103.6 & 8.9 & 82.4 & 127.0 \\
\hline & $50-59$ & 107 & 105.0 & 7.9 & 81.5 & 123.0 \\
\hline & $60-69$ & 103 & 104.1 & 7.5 & 75.0 & 119.0 \\
\hline & $70-79$ & 96 & 105.5 & 7.7 & 86.0 & 122.0 \\
\hline & $80-$ & 91 & 104.6 & 8.2 & 83.0 & 124.0 \\
\hline & Total & 904 & 101.8 & 8.9 & 66.0 & 129.5 \\
\hline \multirow{8}{*}{ City of Zagreb } & -29 & 221 & 96.3 & 7.7 & 80.0 & 122.0 \\
\hline & $30-39$ & 76 & 104.2 & 9.3 & 85.0 & 127.0 \\
\hline & $40-49$ & 84 & 104.9 & 9.7 & 85.0 & 133.0 \\
\hline & $50-59$ & 83 & 106.9 & 9.5 & 77.5 & 131.0 \\
\hline & $60-69$ & 80 & 104.7 & 8.3 & 84.0 & 119.0 \\
\hline & $70-79$ & 70 & 104.1 & 9.0 & 83.0 & 121.0 \\
\hline & $80-$ & 72 & 106.5 & 8.2 & 80.0 & 126.0 \\
\hline & Total & 686 & 102.4 & 9.6 & 77.5 & 133.0 \\
\hline
\end{tabular}




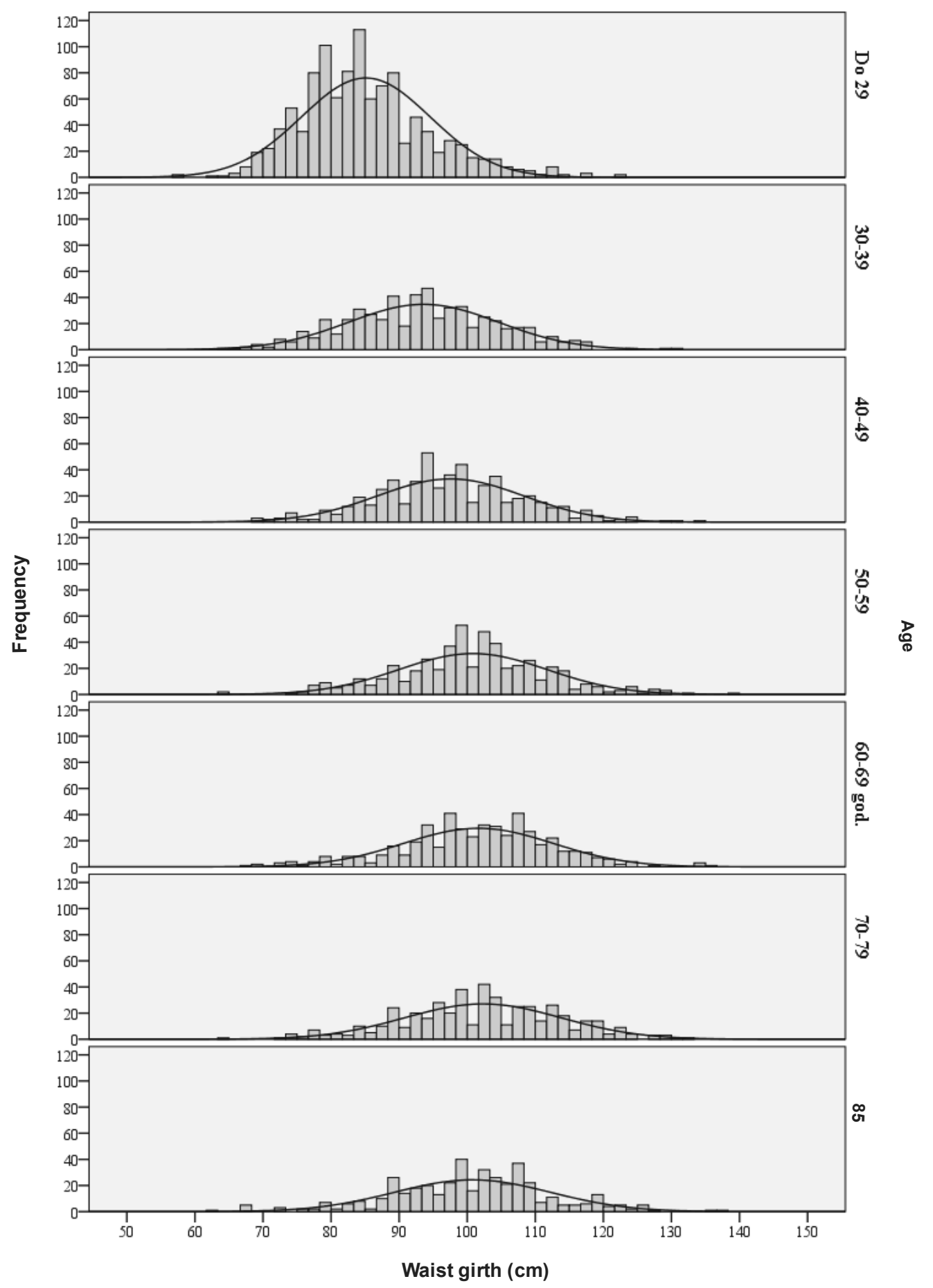

Figure 6. Distribution of waist girths of men by age groups $(N=4,090)$

shows differences in the chest girth of the youngest and oldest age groups from 10 to $15 \mathrm{~cm}$.

The results of analysis of age groups and waist girth in men according to the regions of Croatia largely coincide with those of the chest girth. The mean values of waist girth of subjects changed significantly by age in all regions. A significant shift is observed in the distribution of observed girth to higher values from the youngest age group aged 20-29 years up to the group aged 60-69 years. Stagnation is observed in the group aged 70-79 years (a higher increase is observed in Dalmatia), and equally in all the regions of Croatia (a lower decline in the oldest age group). The differences in waist girth in the youngest men and in men older than 80 years reach almost $20 \mathrm{~cm}$, and the lack of interaction can be seen in less entanglement of the regions, unlike, for example in chest girths (Figure 8). The study investigated the mean values of anthropometric measures (chest girths and waist girths) and regional and age differences of the established values of chest and waist girths of the male population.

By applying the results of mean values of the chest and waist girth, and based on the data laid down in the Croatian technical report, the most common body types within all five regions 
Table 5. Basic parameters of distribution of waist girth of men $(\mathrm{cm})$ by the regions and age groups

\begin{tabular}{|c|c|c|c|c|c|c|}
\hline \multirow{2}{*}{ Region } & \multirow{2}{*}{ Age } & \multirow{2}{*}{$\mathbf{N}^{\mathrm{a}}$} & \multirow{2}{*}{$\bar{x}$} & \multirow{2}{*}{$\mathbf{s}^{c}$} & \multicolumn{2}{|c|}{ Range } \\
\hline & & & & & Min. & Max. \\
\hline \multirow{8}{*}{$\begin{array}{c}\text { Primorje Gorski Kotar } \\
\text { Region }\end{array}$} & -29 & 250 & 86.2 & 9.7 & 68.0 & 118.0 \\
\hline & $30-39$ & 128 & 94.4 & 11.7 & 65.0 & 125.0 \\
\hline & $40-49$ & 125 & 98.9 & 11.4 & 71.0 & 134.0 \\
\hline & $50-59$ & 108 & 100.4 & 10.5 & 78.0 & 132.0 \\
\hline & $60-69$ & 117 & 101.4 & 12.2 & 70.0 & 135.0 \\
\hline & $70-79$ & 111 & 102.9 & 11.9 & 73.0 & 129.0 \\
\hline & $80-$ & 98 & 100.2 & 10.0 & 73.0 & 122.0 \\
\hline & Total & 937 & 96.0 & 12.6 & 65.0 & 135.0 \\
\hline \multirow{8}{*}{ Slavonia } & -29 & 195 & 85.2 & 9.5 & 69.0 & 115.0 \\
\hline & $30-39$ & 114 & 93.5 & 9.7 & 72.0 & 130.9 \\
\hline & $40-49$ & 110 & 97.0 & 10.1 & 70.0 & 129.0 \\
\hline & $50-59$ & 121 & 100.4 & 11.3 & 78.0 & 140.0 \\
\hline & $60-69$ & 109 & 102.8 & 10.4 & 73.0 & 136.0 \\
\hline & $70-79$ & 102 & 102.8 & 10.5 & 81.0 & 131.0 \\
\hline & $80-$ & 79 & 103.7 & 12.5 & 63.0 & 138.0 \\
\hline & Total & 830 & 96.4 & 12.5 & 63.0 & 140.0 \\
\hline \multirow{8}{*}{ Central Croatia } & -29 & 186 & 85.4 & 9.5 & 65.9 & 113.0 \\
\hline & $30-39$ & 108 & 93.8 & 10.1 & 70.0 & 117.0 \\
\hline & $40-49$ & 91 & 98.7 & 10.0 & 75.0 & 130.5 \\
\hline & $50-59$ & 96 & 102.3 & 11.0 & 77.0 & 130.0 \\
\hline & $60-69$ & 81 & 103.8 & 11.0 & 73.0 & 127.0 \\
\hline & $70-79$ & 90 & 101.9 & 12.2 & 65.0 & 128.0 \\
\hline & $80-$ & 81 & 100.4 & 10.6 & 68.0 & 126.0 \\
\hline & Total & 733 & 96.2 & 12.6 & 65.0 & 130.5 \\
\hline \multirow{8}{*}{ Dalmatia } & -29 & 233 & 85.2 & 9.2 & 58.0 & 112.5 \\
\hline & $30-39$ & 149 & 91.8 & 11.5 & 66.0 & 130.0 \\
\hline & $40-49$ & 125 & 95.7 & 11.0 & 70.0 & 125.0 \\
\hline & $50-59$ & 107 & 100.2 & 9.9 & 76.5 & 130.0 \\
\hline & $60-69$ & 103 & 99.9 & 10.4 & 68.0 & 121.0 \\
\hline & $70-79$ & 96 & 103.7 & 10.8 & 76.0 & 133.0 \\
\hline & $80-$ & 91 & 100.0 & 12.9 & 67.0 & 126.0 \\
\hline & Total & 904 & 94.6 & 12.5 & 58.0 & 133.0 \\
\hline \multirow{8}{*}{ City of Zagreb } & -29 & 221 & 83.4 & 9.3 & 62.0 & 123.0 \\
\hline & $30-39$ & 76 & 95.4 & 11.7 & 72.0 & 118.0 \\
\hline & $40-49$ & 84 & 97.7 & 10.7 & 69.0 & 121.0 \\
\hline & $50-59$ & 83 & 101.2 & 12.2 & 64.0 & 130.0 \\
\hline & $60-69$ & 80 & 100.4 & 10.5 & 73.0 & 122.5 \\
\hline & $70-79$ & 70 & 99.2 & 12.3 & 74.0 & 124.0 \\
\hline & $80-$ & 72 & 99.6 & 11.3 & 73.0 & 127.0 \\
\hline & Total & 686 & 93.9 & 13.1 & 62.0 & 130.0 \\
\hline
\end{tabular}

${ }^{\text {a }}$ several cases, ${ }^{\mathrm{b}}$ arithmetic mean, ${ }^{\mathrm{c}}$ standard deviation 


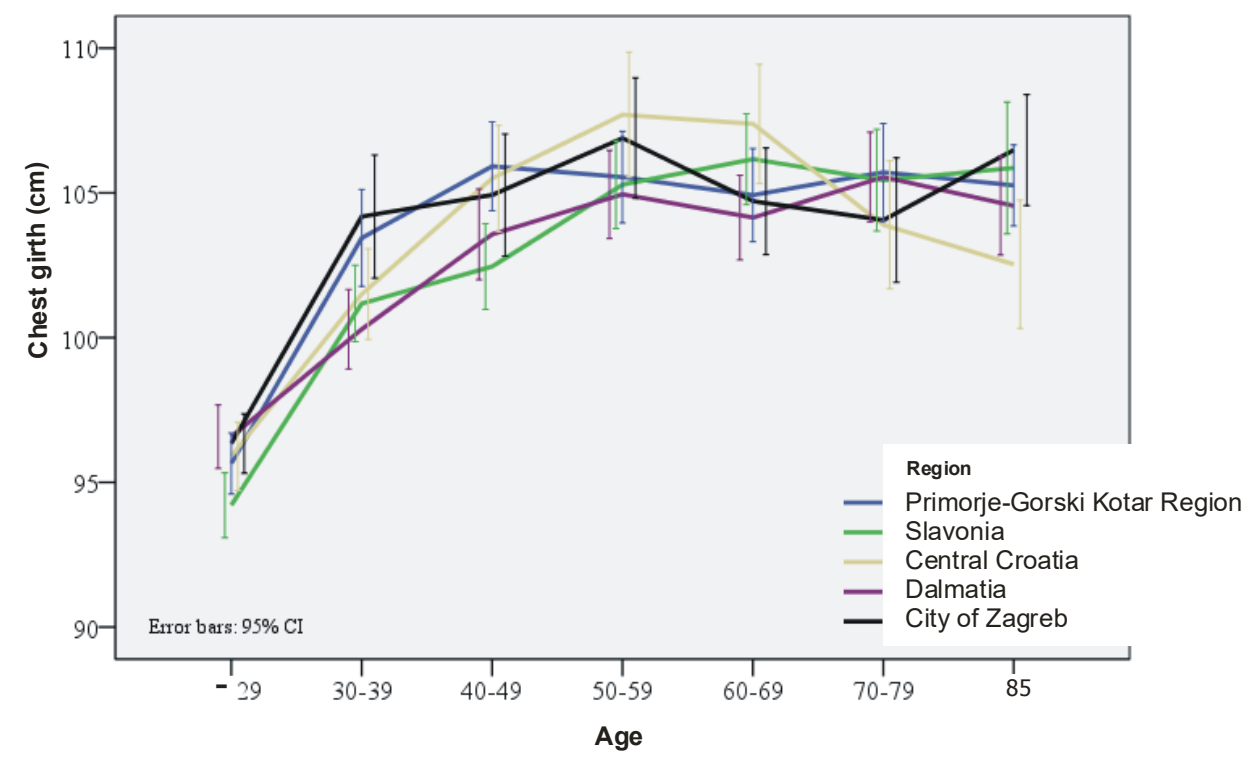

Figure 7. Mean chest girth of men by age groups and regions $(N=4,090)$

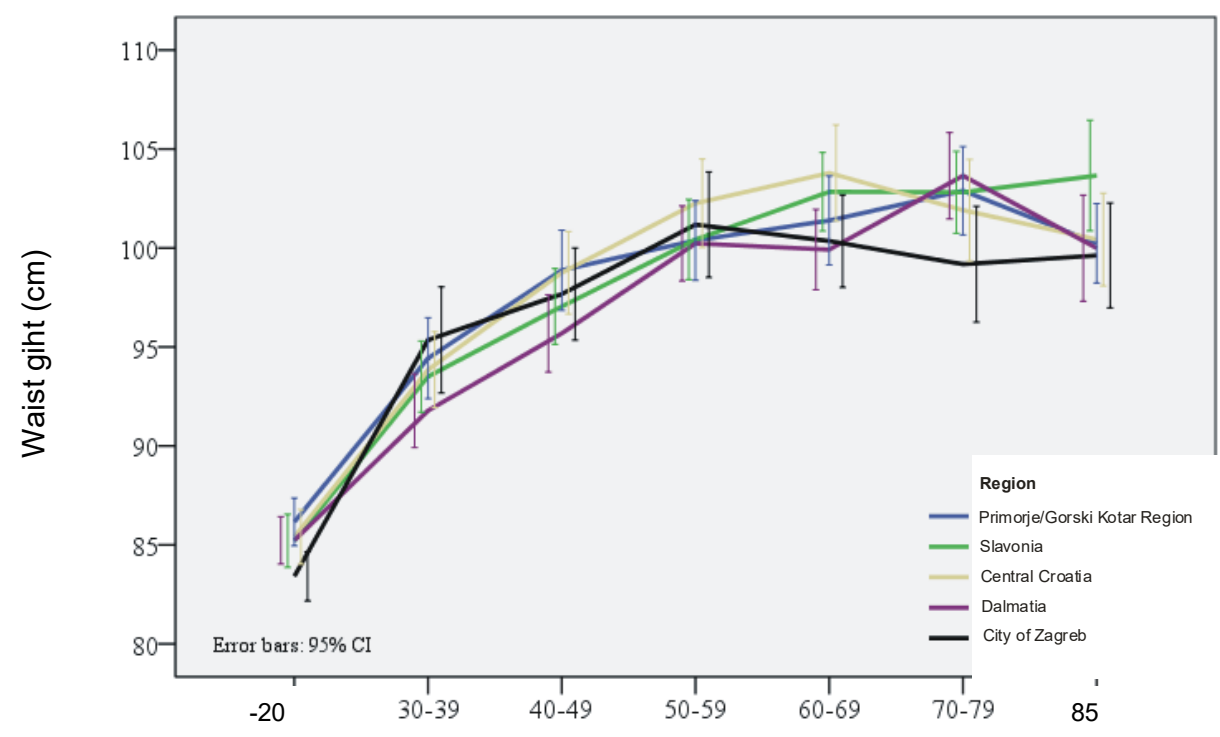

Figure 8. Mean waist girth of men by age groups and regions $(N=4,090)$

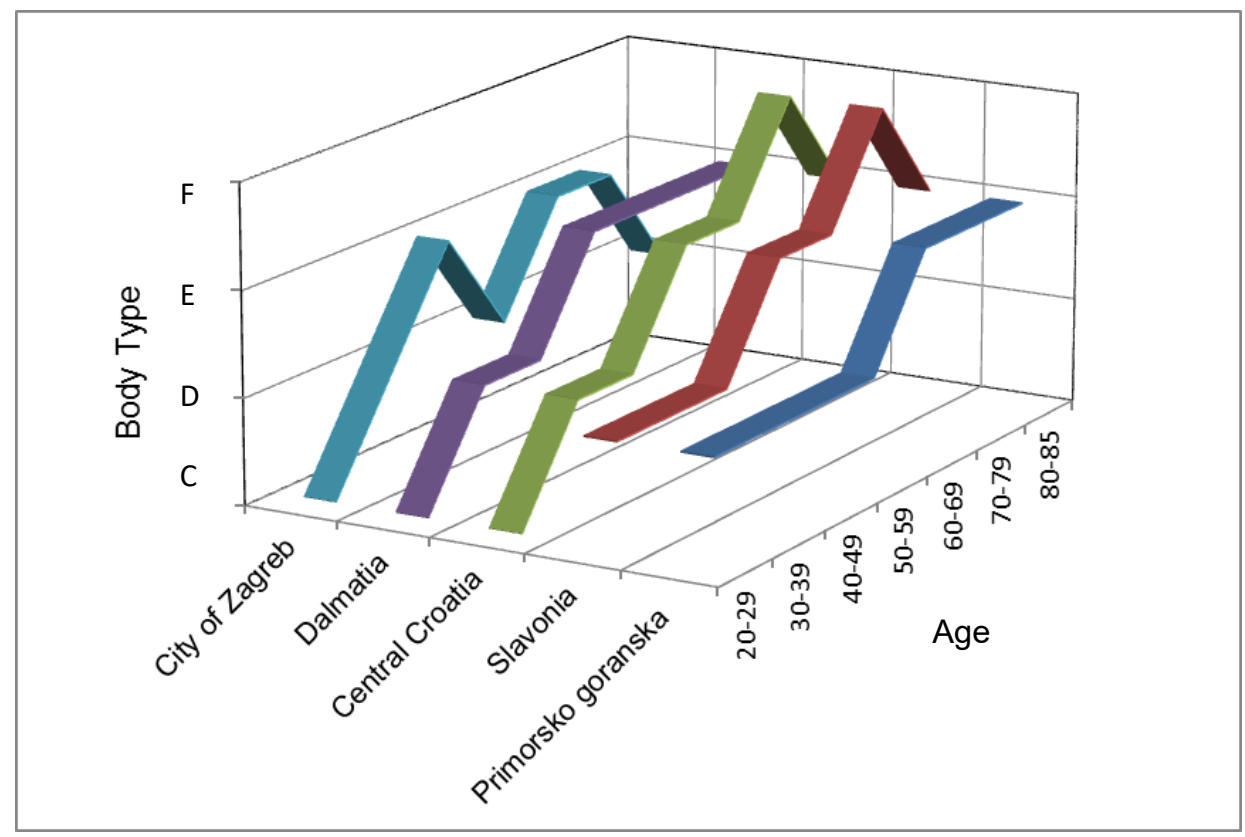

Figure 9. Body types mostly present in the regions of the Republic of Croatia 
Table 6. Body types within five regions of the Republic of Croatia

\begin{tabular}{|c|c|c|c|c|c|c|c|c|c|c|c|c|c|c|c|}
\hline \multirow{3}{*}{ Age } & \multicolumn{15}{|c|}{ Regions of the Republic of Croatia } \\
\hline & \multicolumn{3}{|c|}{$\begin{array}{l}\text { Primorje Gorski } \\
\text { Kotar Region }\end{array}$} & \multicolumn{3}{|c|}{ Slavonia } & \multicolumn{3}{|c|}{ Central Croatia } & \multicolumn{3}{|c|}{ Dalmatia } & \multicolumn{3}{|c|}{ City of Zagreb } \\
\hline & $\begin{array}{l}\text { Chest } \\
\text { girth } \\
(\bar{x})\end{array}$ & $\begin{array}{l}\text { Waist } \\
\text { girth } \\
(\bar{x})\end{array}$ & $\begin{array}{c}\text { Body } \\
\text { type }\end{array}$ & $\begin{array}{c}\text { Chest } \\
\text { girth } \\
(\bar{x})\end{array}$ & $\begin{array}{l}\text { Waist } \\
\text { girth } \\
(\bar{x})\end{array}$ & $\begin{array}{c}\text { Body } \\
\text { type }\end{array}$ & $\begin{array}{l}\text { Chest } \\
\text { girth } \\
(\bar{x})\end{array}$ & $\begin{array}{c}\text { Waist } \\
\text { girth } \\
(\bar{x})\end{array}$ & $\begin{array}{c}\text { Body } \\
\text { type }\end{array}$ & $\begin{array}{c}\text { Chest } \\
\text { girth } \\
(\bar{x})\end{array}$ & $\begin{array}{c}\text { Waist } \\
\text { girth } \\
(\bar{x})\end{array}$ & $\begin{array}{c}\text { Body } \\
\text { type }\end{array}$ & $\begin{array}{l}\text { Chest } \\
\text { girth } \\
(\bar{x})\end{array}$ & $\begin{array}{c}\text { Waist } \\
\text { girth } \\
(\bar{x})\end{array}$ & $\begin{array}{c}\text { Body } \\
\text { type }\end{array}$ \\
\hline-29 & 96 & 86 & $\mathrm{D}$ & 94 & 85 & $\mathrm{D}$ & 96 & 85 & C & 97 & 85 & $\mathrm{C}$ & 97 & 83 & $\mathrm{C}$ \\
\hline $30-39$ & 103 & 100 & $\mathrm{D}$ & 101 & 94 & $\mathrm{D}$ & 102 & 94 & $\mathrm{D}$ & 100 & 92 & $\mathrm{D}$ & 104 & 95 & $\mathrm{D}$ \\
\hline $40-49$ & 106 & 100 & $\mathrm{D}$ & 103 & 97 & $\mathrm{D}$ & 106 & 99 & $\mathrm{D}$ & 104 & 96 & $D$ & 105 & 98 & $E$ \\
\hline $50-59$ & 106 & 100 & $D$ & 105 & 100 & $E$ & 108 & 102 & $E$ & 105 & 100 & $E$ & 107 & 101 & $D$ \\
\hline $60-69$ & 105 & 101 & $E$ & 106 & 103 & $E$ & 107 & 104 & $E$ & 104 & 100 & $E$ & 105 & 100 & $E$ \\
\hline $70-79$ & 106 & 103 & $E$ & 105 & 103 & $F$ & 104 & 102 & $F$ & 106 & 104 & $E$ & 104 & 99 & $E$ \\
\hline $80-85$ & 105 & 100 & $E$ & 106 & 104 & $E$ & 103 & 100 & $E$ & 105 & 100 & $E$ & 107 & 100 & $D$ \\
\hline
\end{tabular}

were established according to the age groups, Table 6 [9].

Body types are graphically shown in Figure 9.

The most common body types within all five regions are types $D$ and $E$. The presence of types $C$ and $F$ has also been established. Type $C$ is present within three regions, in the youngest age group, and type $F$ is present within two regions in the group aged $70-79$ years.

\section{CONCLUSION}

The average values of the observed body measurements of test subjects of the Republic of Croatia indicate changes determined with increasing age. The results of anthropometric measurements indicate an increase in the chest girth of test subjects of the Primorje-Gorski Kotar Region, the City of Zagreb and Central Croatia aged 20-59 years and the equalization with values of the other regions within the last two age groups. Furthermore, the analysis of the results of waist girth shows an increase in the average values of test subjects aged 20-59 years across all five regions of Croatia. Both girths increase with age, except in the last two groups. The difference between the minimum and maximum average values of the chest girths of the test subjects amounts to 10 $\mathrm{cm}$, and it is slightly higher in waist girth, amounting to $20 \mathrm{~cm}$. The above results provide a detailed insight into the changes in body dimensions dependent on age, and a database for further research of body types has been created. Based on the test subjects, present body types are C, D, E and F, while the most common were $D$ and $E$. About to age groups, the most common type among younger test subjects is type $D$, while for older test subjects it is type $\mathrm{E}$. The presence of types $C$ and $F$ is significantly lower, and the results show the prevalence of type $\mathrm{C}$ in the youngest age group in the three regions (Central Croatia, Dalmatia and Zagreb), while body type $\mathrm{F}$ covers the age group 70-79 years in Central Croatia and Slavonia. The most similar regions as regards body type, seen in all age groups, are Primorje-Gorski Kotar Region and
Slavonia, then Central Croatia and Dalmatia. In the City of Zagreb, body types mostly differ with respect to age of the test subjects.

The information provided gives clothing manufacturers some of the most important information required to complement clothing sizes and the aim of the study is fulfilled.

Furthermore, by choosing appropriate clothing sizes at the regional level, garment manufacturers would be able to launch their products more efficiently. Problems related to non-fitting clothing for customers could be significantly reduced by affecting the variations of body dimensions of inhabitants in a region within a larger unity (Republic of Croatia).

\section{References}

[1] Ujević, D., Doležal, K. (2010). Croatian Anthropometric System in theory and practice, Theoretical Aspects and Application of Croatian Anthropometric System, (Ujević, D. ed.). Faculty of Textile Technology University of Zagreb, Croatia

[2] Vinković, M. (2014). Likovno projektiranje odjeće I, Sveučilište u Zagrebu, Tekstilno-tehnološki fakultet, Zagreb, Croatia

[3] Hsu, CH., Lin, HF., Wang, MJ. (2007). Developing Female Size Charts for Facilitating Garment Production by using Data mining, Journal of the Chinese Institute of Industrial Engineers, 24(3), 245-251.

[4] Chun-Yoon, J., and Jasper, C. R. (1993). Garment-sizing Systems: An International Comparison, International Journal of Clothing Science and Technology, 5 (5), 28-37.

[5] HRN EN 13402 (Part 1-3): 2008, Size designation of clothes - Part 1: Terms, definitions and body measurement procedure (ISO 3635:1981, MOD; EN 13402-1:2001), Part 2: Primary and secondary dimensions (EN 13402-2:2002), Part 3: Measurements and intervals (EN 13402-3:2004).

[6] Ujević, D., Hrastinski, M. (2010). Contribution to the support dana for new Croatian Standards for garment and footwear size and their designations, (Ujević, D. ed.). Faculty of Textile Technology University of Zagreb, Croatia 
[7] Ujević, D., Rogale, D., Hrastinski, M. (2010). Tehnike konstruiranja i modeliranja odjeće, treće dopunjeno $i$ prošireno izdanje, (Dragčević, Z. ed.). Zrinski d. d., Zagreb, Croatia

[8] Ujević, D., Szirovicza, L., Dimec, M. (2003). Description of the investigation and comparison of the system of clothing sizes. Tekstil, 52 (12), 611-620.

[9] Anthropometric System - Measuring and Size Designation of Clothes and Footwear, Croatian Technical Report, HRI 1148:2012 hr, HZN, February 2012, ICS: 01.040.61:61.020.

[10] Ujević, D., Rogale, D., Hrastinski, M, et. al. (2004). Croatian Anthropometric System - Path to Europe, Proceedings of the Professional Conference (Ujević, D. ed), Faculty of Textile Technology, University of Zagreb, Croatia

[11] Ujević, D. et al. (2006). Hrvatski antropometrijski sustav - Fakultetski priručnik, Tekstilno-tehnološki fakultet Sveučilišta u Zagrebu, Zagreb,

[12] Ujević, D. et al. (2006). Antropometrijski instrumenti $i$ njihova primjena - Podloga za nove hrvatske norme za veličinu odjeće i obuće, (Ujević, D. ed). Tekstilnotehnološki fakultet Sveučilišta u Zagrebu, Zagreb,
[13] Ujević, D. et al. (2007). New Anthropometric Instruments. Coll. Antropol 31(4), 1031-1038.

[14] StatSoft, Inc. Statistica (data analysis software system), version 9.1., http://www.statsoft.com (2010, accessed 2 April 2011).

[15] Horvat, J. (1995). Statistics by SPSS/PC+. Osijek: J. J. Strossmayer University Osijek, Faculty of Economics in Osijek, Croatia

[16] Pallant, J. (2011). SPSS Survival manual: Astep by step guide to data analysis using SPSS for Windows (Version 15). Third Edition. Mikro knjiga, Beograd

[17] Doležal, K. (2012). Investigation of the Influence of Regional Characteristics of the Physical Dimensions Garment Construction and Fit. PhD Thesis, University of Zagreb, Croati.

[18] Momirović, K., Gredelj, M., Szirovicza, L. (1977). Methods of multivariate analysis (Statistical seminar - II), Zavod za produktivnost, Zagreb

[19] Dillon, WR., Goldsein, M. (1984). Multivariate Analysis, Methods and Applications. John Wiley \& Sons, New York 